\title{
A STUDY OF INTESTINAL PARASITIC INFESTATIONS AMONG SCHOOL CHILDREN IN BAGEPALLI TALUK, CHIKKABALLAPUR DISTRICT, KARNATAKA- A CROSS- SECTIONAL SCHOOL SURVEY
}

N. Ramakrishna Reddy ${ }^{1}$, Riyaz Basha. S². $^{2}$

1. Associate Professor. Department of Community Medicine, Bangalore Medical College \& Research Institute,
Bangalore.
2. Associate Professor. Department of Community Medicine, Bangalore Medical College \& Research Institute,
Bangalore.

\section{CORRESPONDING AUTHOR:}

Dr. N. Ramakrishna Reddy,

Associate professor,

Department of Community Medicine,

Bangalore Medical College \& Research Institute,

KR Road, Bangalore -560002,

E-mail: nrkr1234@yahoo.co.in

Ph: 00919448065536.

ABSTRACT: A school survey was conducted to study the epidemiology of intestinal parasitic infestations.

Among school children in Bagepalli Taluk, Chikkaballapur District, Karnataka, a total of 438 stool samples were collected from school children selected from 5 rural and 3 urban schools. The stool samples collected were examined for presence of parasitic infections by direct microscopic examination. Prevalence of intestinal parasites was $19.8 \%$. There was a significant difference in prevalence between urban $(16.3 \%)$ and rural $(23.0 \%)$ school samples. Giardia lamblia (12.6\%), Ascaris lumbricoides (4.3\%) and Entamoeba histolytica (1.8\%) were the commonest parasites isolated. The results indicate that intestinal parasitic infestations among school children are mainly water-borne. The burden of parasitic infestations among the school children, and poor sanitary conditions in the schools, should be taken seriously by public health and school authorities. Our survey results show the need for school periodic deworming, health education and improvement of school sanitation under school health program.

KEY WORDS: Prevalence, Intestinal parasites, school children, rural)

INTRODUCTION: The World Health Organization (WHO) estimates that over one billion of the world's population is chronically infested with soil-transmitted helminths and 200 million are Infested with schistosomes1. The high prevalence of these infestations is closely correlated to poverty, poor environmental hygiene and impoverished health services1,2.. Intestinal helminths infestations are the most common infestations among school age children, and they tend to occur in high intensity in this age group2,3. Also, helminthic infestations lead to nutritional deficiency and impaired physical development, which will have negative consequences on cognitive function and learning ability4,5. Like other developing countries, intestinal parasitic infestation is a public health problem in India. A study on the prevalence of intestinal parasites among school children conducted in two rural villages of Chitwan District, Nepal estimated a prevalence of $44.0 \% 6$. Similar results were reported from different parts of India7-8. Such epidemiological surveys on the intestinal parasitic infestations among school 
children are important in this country since they reflect the sanitary conditions of schools and generate data that are essential to formulate strategies for the control of intestinal parasitic infestations among school children we undertook the present study to estimate the prevalence of intestinal parasitic infestations among school children in Bagepalli Taluk, Chikkaballapur District, Karnataka.

METHODS: Ethical clearance for the study was obtained from Institute ethics committee of Bangalore Medical college and Research institute. We carried out a school survey with district public health department from June to December 2009 Bagepalli Taluk, Chikkaballapur District, Karnataka. The survey involved 162 primary schools, 118 of which were located in the 129 villages and 44 in Bagepalli town. Five per cent of the schools from town and suburban areas and villages were selected by systematic random sampling method after listing schools from Bagepalli town and the villages separately. Thus, a total of 8 schools - 5 from the rural areas and 3 from Bagepalli town were selected for the study. Schools in the municipal corporation limits of Bagepalli town were considered as urban while those outside the limits were considered as rural. This was based on the classification based on Department of Revenue, Government of Karnataka which states that areas with population $>50,000$ are termed as Urban areas( town) and those below 50,000 termed as rural(Village). All children present in school on the day of the survey were enrolled for the study. Those children absent on the day of survey were excluded which was found to be negligible number. The purpose of the study and the procedure for stool sample collection were explained to school teachers, children and their parents in each school and written informed consent was obtained from parents. Plastic containers with identification numbers and names were distributed to all the children, which were used to collect stool sample from each child. Information about name, sex, age, school grade and the result of stool examination for each child was recorded on the stool examination forms by the field workers. Stool samples were examined within 12 hours for the cysts and ova of intestinal parasites by direct microscopic examination at the Bagepalli hospital. The data were entered into the computer using SPSS latest version and analysed. The results were expressed as rates and proportions. Chi square test of statistical significance was applied to study the association between prevalence of intestinal parasites and the demographic factors. P value $<0.05$ was considered as significant.

RESULTS: A total of 438 stool samples were examined. A majority (84.1\%) of them were in the 6- 10 years age group (Table 1).The prevalence of intestinal parasites was $19.8 \%$. There was no significant difference in the prevalence of intestinal parasites according to age and gender of the school children. Prevalence was highest in the 6-10 years age group (20.3\%), while prevalence was $19.9 \%$ and $19.7 \%$ among male and female children respectively. Prevalence of infestation was higher in rural $(23.0 \%)$ than urban $(16.3 \%)$ schools and the difference was statistically significant (Table 2). The cyst positive rate of intestinal protozoal infestation was $12.6 \%$ for Giardia lamblia and $1.8 \%$ for Entamoeba histolytica. The egg positive rates for helminthic infestation were 4.3\%, 0.7\%, 0.2\%for Ascaris lumbricoides, Trichuris trichura and, Hymenolepis nana respectively. $1,1 \%$ had mixed infestations. (Table 3 ).

DISCUSSION: The prevalence of intestinal parasites in the present study was $19.8 \%$. There was a significant difference in the prevalence between urban and rural schools. Giardia lamblia (14.6\%) and Ascaris lumbricoides (2.1\%) were the most common organisms detected. There 
was no significant difference in prevalence of intestinal parasites according to age and gender of the school children. The prevalence of intestinal parasitic infections estimated in this study was less than in a previous study conducted in two villages of Chitwan District, Nepal 6. Studies from other countries, namely, Philippines, Cambodia and Turkey, have reported a higher prevalence of intestinal parasites among school children 11-13. This could be attributed to the different geographical location and time of the survey, i.e., Rainy (June to December) which is a low transmission season. Also, the direct microscopic examination method used for detection of parasites has a low rate of parasite detection. It was the only feasible method to examine the stool samples since the study was community-based. The prevalence of protozoal infection was higher than that of helminths, and Giardia lamblia was the commonest intestinal parasite isolated. Similar results have been reported from a previous study in other parts of India7-10. This is in contrast to surveys from Philippines and Cambodia, which reported a higher prevalence of helminths11,12. This suggests that water-borne parasitic infections are very common among school children in Bagepalli taluk, Chikkaballapur which reflects the poor sanitary conditions existing in the schools. Few studies from other southern states have reported A. lumbricoides as the most common helminths among school children7,8,9 while other studies reported hook worm as the most common helminths8. This is in contrast to findings from the present study in which A. lumbricoides was the commonest. This difference could be as a result of variation in the geographic locations of the areas where the surveys were conducted. The higher prevalence of parasitic infections in rural schools than urban schools could be due to low socio-economic status, poor hygienic habits and lack of sanitation prevailing in the rural schools.. This difference was statistically significant, indicating that hook worm infestation is more prevalent in rural than urban areas. Since hook worm is a soil-borne helminths, rural conditions favour its transmission.

CONCLUSION: The results of this study re-emphasise the fact that intestinal parasitic infestation among school children in the study area is mainly water-borne. The burden of parasitic infestations among the school children, coupled with the poor sanitary conditions in the schools, should be regarded as an issue of public health priority. This strongly supports the need for school health programmes that will involve periodic deworming, health education and improvement of school sanitation

Table 1: Distribution of school children according to age gender and school location (urban/rural). Age Group (Years)

\begin{tabular}{|c|c|c|c|}
\hline Character & $6-10$ & $>10$ & Total \\
\hline Male' & $200(45.7 \%)$ & 41 & $241(55 \%)$ \\
\hline Female & $168(38.4 \%)$ & 29 & $197(45 \%)$ \\
\hline Location & & $(6.6 \%)$ & \\
\hline Urban & 175 (39.9\%) & & $203(46.3)$ \\
\hline Rural & $193(44.1 \%)$ & $42(9.6 \%)$ & $235(53.7)$ \\
\hline & & & 438 \\
\hline
\end{tabular}


Table 2 Prevalence of intestinal parasites according to age, gender and location of school (urban/rural).

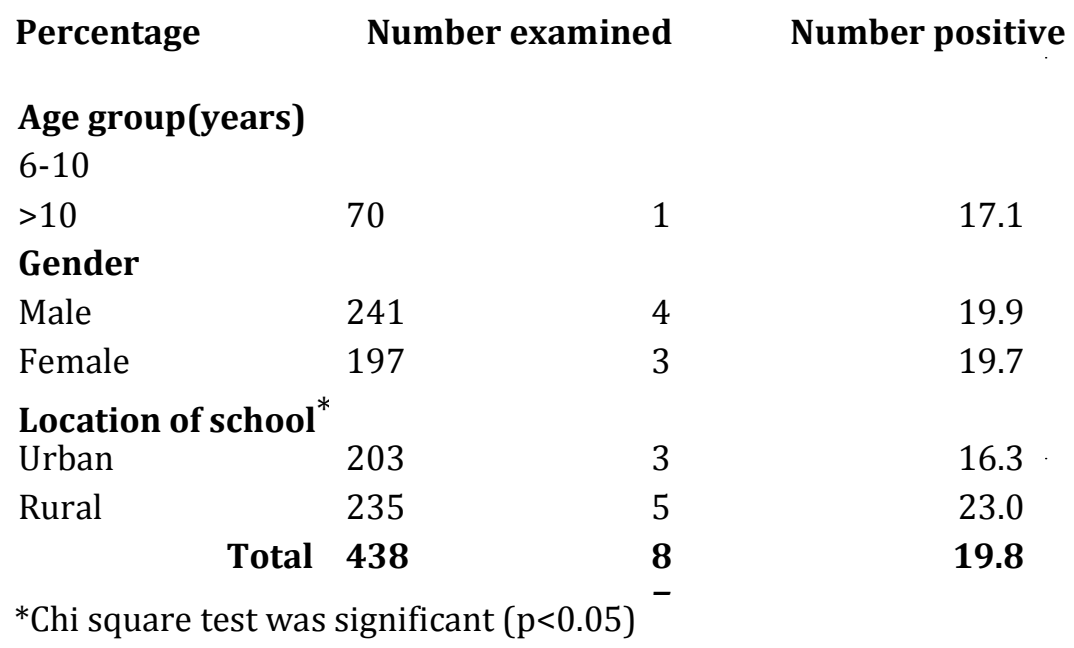

Table 3. Intestinal parasites isolated according to age, gender and location of school (urban/rural).

\begin{tabular}{|c|c|c|c|c|c|c|c|}
\hline \multirow[b]{2}{*}{ Parasite } & \multicolumn{2}{|c|}{ Age group(years) } & \multicolumn{2}{|c|}{ Gender } & \multicolumn{2}{|c|}{ Location of school } & \multirow[b]{2}{*}{ Total } \\
\hline & $6-10$ & $>10$ & Male & Female & Urban & Rural & \\
\hline Giardia lamblia & $\begin{array}{l}4 \\
9\end{array}$ & $\begin{array}{c}6 \\
(1.7 \%\end{array}$ & $\begin{array}{l}2 \\
9\end{array}$ & $\begin{array}{l}2 \\
6\end{array}$ & $\begin{array}{l}2 \\
4\end{array}$ & $\begin{array}{l}3 \\
1\end{array}$ & $\begin{array}{l}5 \\
5\end{array}$ \\
\hline $\begin{array}{l}\text { Ascaris } \\
\text { lumbricoides }\end{array}$ & $\begin{array}{l}1 \\
6\end{array}$ & $\begin{array}{c}3 \\
(0.6 \%\end{array}$ & $\begin{array}{l}1 \\
0\end{array}$ & $\begin{array}{c}9 \\
(2.0 \%\end{array}$ & $\begin{array}{c}8 \\
(1.8 \%\end{array}$ & $\begin{array}{l}1 \\
1\end{array}$ & $\begin{array}{l}1 \\
9\end{array}$ \\
\hline $\begin{array}{l}\text { Entamoeba } \\
\text { histolytic }\end{array}$ & $\begin{array}{c}6 \\
(1.4 \%\end{array}$ & $\begin{array}{c}2 \\
(0.4 \%\end{array}$ & $\begin{array}{c}5 \\
(1.1 \%\end{array}$ & $\begin{array}{c}3 \\
(0.7 \%\end{array}$ & $\begin{array}{c}2 \\
(0.4 \%\end{array}$ & $\begin{array}{c}6 \\
(1.4 \%\end{array}$ & $\begin{array}{c}8 \\
(1.8 \%\end{array}$ \\
\hline $\begin{array}{l}\text { Trichuris } \\
\text { trichura }\end{array}$ & $\begin{array}{c}2 \\
0.5 \%\end{array}$ & $\begin{array}{c}1 \\
(0.2 \%\end{array}$ & $\begin{array}{c}2 \\
(0.5 \%\end{array}$ & $\begin{array}{c}1 \\
(0.2 \%\end{array}$ & $\begin{array}{c}1 \\
(0.2 \%\end{array}$ & $\begin{array}{c}2 \\
(0.5 \%\end{array}$ & $\begin{array}{c}3 \\
0.7 \%\end{array}$ \\
\hline $\begin{array}{l}\text { Hymenolep } \\
\text { is nana }\end{array}$ & $\begin{array}{c}1 \\
0.2 \%\end{array}$ & & $\begin{array}{c}1 \\
0.2 \%\end{array}$ & & & $\begin{array}{c}1 \\
0.2 \%\end{array}$ & $\begin{array}{c}1 \\
(0.2 \%\end{array}$ \\
\hline Mixed infection & $\begin{array}{c}1 \\
(0.2 \%\end{array}$ & & $\begin{array}{c}1 \\
(0.2 \%\end{array}$ & & & $\begin{array}{c}1 \\
(0.2 \%\end{array}$ & $\begin{array}{c}1 \\
(0.2 \%\end{array}$ \\
\hline
\end{tabular}

\section{REFERENCES:}

1. Montresor. A, Crompton DWT, Hall. A, Bundy DAP and Savioli. L. Guidelines for the Evaluation of Soil Transmitted Helminthisiases and Schistosomiasis at Community Level. Geneva: World Health Organization, WHO/CTC/SIP/98.

2. Albonico M, Crompton DWT and Savioli L. Control strategies for human intestinal helminth infections. Adv Parasitol 1999; 42: 276-341. 
3. Savioli L, Bundy DAP and Tomkins A. Intestinal parasitic infections: a soluble public health problem. Trans R Soc Trop Med Hyg 1992; 86: 353-354.

4. Nokes $C$ and Bundy DAP. Does helminth infection affect mental processing and educational achievement? Parasitol Today 1994; 10: 14-18.

5. Simeon DT and Grantham-McGregor S. Nutritional deficiencies and children behaviour and mental development. Nutr Res Rev 1990; 3: 1-24.

6. Tai-Soon YONG, Seobo SIM, Jongweon LEE, Heechoul OHRR, Myung-Ho KIM, Hyunsoo KIM. A small-scale survey on the status of intestinal parasite infections in rural villages in Nepal. Korean J Parasitol 2000; 38(4): 275-257.

7. Fernandez MC, Verghese S, Bhuvaneswari R, Elizabeth SJ, Mathew T, Anitha A, Chitra AK. Paul I, Gnanamani G, Nallam NR. Intestinal helminth infections among school children in Visakhapatnam. Indian J Pediatr. 1999; 66(5):669-73.

8. Wani SA, Ahmad F, Zargar SA, Amin A, Dar ZA, Dar PA. Intestinal helminthiasis in children of gurez valley of jammu and kashmir state, India. J Glob Infect Dis. 2010; 2(2):91-4.

9. Rayan P, Verghese S, McDonnell PA. Geographical location and age affects the incidence of parasitic infestations in school children. Indian J Pathol Microbiol. 2010; 53(3):504-8.

10. A comparative study of the intestinal parasites prevalent among children living in rural and urban settings in and around Chennai. J Commun Dis. 2002; 34(1):35-9.

11. Kim BJ, Ock MS, Chung DI, Yong TS and Lee KJ. The intestinal parasite infection status of inhabitants in the Roxas city, The Philippines. Korean J Parasitol 2003; 41(2):

113-115.

12. Lee KJ, Bae YT, Kim DH, Deung YK, Ryang YS, Kim HJ, Im KI and Yong TS. Status of intestinal parasites infection among primary school children in Kampongcham, Cambodia. Korean J Parasitol 2002; 40(3): 153-155.

13. Ulukanligil M and Seyrek A. Demographic and parasitic infection status of schoolchildren and sanitary conditions of schools in Sanliurfa, Turkey. BMC Pub Health

2003; 3(1): 29. 